\title{
Phytate levels in diverse rat tissues: influence of dietary phytate
}

\author{
F. Grases*, B. M. Simonet, R. M. Prieto and J. G. March \\ Laboratory of Renal Lithiasis Research, University of Balearic Islands, Palma de Mallorca, Spain
}

(Received 1 June 2000 - Revised 5 March 2001 - Accepted 12 March 2001)

\begin{abstract}
Phytate (inositol hexaphosphate; $\operatorname{Ins} P_{6}$ ) was determined in rat tissues fed on diets with different phytate contents, using a $\mathrm{GC}$-mass detection methodology that permitted the evaluation of the total amount of this substance present in such tissues. The highest $\operatorname{Ins} P_{6}$ concentrations were found in brain $\left(5 \cdot 89 \times 10^{-2}\left(\mathrm{SE} 5.7 \times 10^{-3}\right) \mathrm{mg} / \mathrm{g} \mathrm{DM}\right)$, whereas the concentrations detected in kidneys, liver and bone were similar to each other $\left(1.96 \times 10^{-3}\left(\mathrm{SE} 0.20 \times 10^{-3}\right), 3.11 \times 10^{-3}\right.$ (SE $\left.0 \cdot 24 \times 10^{-3}\right), 1 \cdot 77 \times 10^{-3}\left(\mathrm{SE} 0 \cdot 17 \times 10^{-3}\right) \mathrm{mg} / \mathrm{g}$ DM respectively) and 10 -fold less than those detected in brain. When rats were fed on a purified diet in which $\operatorname{Ins} P_{6}$ was undetectable, the Ins $P_{6}$ levels of the organs mentioned earlier decreased dramatically $\left(9.0 \times 10^{-4}, 3.8 \times 10^{-5}\right.$, $1.4 \times 10^{-5} \mathrm{mg} / \mathrm{g} \mathrm{DM}$ in brain, kidneys and liver respectively) and in some cases became undetectable (bone). The addition of $\operatorname{Ins} P_{6}$ to this purified diet led to the increase of Ins $P_{6}$ levels in these tissues. This clearly demonstrated that the majority of the $\operatorname{Ins} P_{6}$ found in organs and tissues has a dietary origin and is not a consequence of endogenous synthesis. Consequently, considering that Ins $P_{6}$ could be involved in some important biological roles, the value of any diet on supplying this substance is noteworthy.
\end{abstract}

Phytate: Bone: Calcium: Zinc

Phytate (inositol hexaphosphate; Ins $P_{6}$ ) has been found in cells at total amounts about $10-100 \mu \mathrm{M}$ (Jackson et al. 1987; Szwergold et al. 1987; Pittet et al. 1989; French et al. 1991; Bunce et al. 1993). A part of Ins $P_{6}$ may be bound to membranes and to proteins and it is not really clear how much is freely soluble. It is important to note that these concentrations have been found using cultures of different cell types treated by $\left[{ }^{3} \mathrm{H}\right]$ inositol in the medium, and the cellular radioactive $\operatorname{Ins} P_{6}$ formed was determined radiometrically after separation by HPLC. The problem in these experiments is that the $\operatorname{Ins} P_{6}$ pool incorporates radioactive inositol so slowly that it may take more than 1 week to reach the equilibrium, and it is possible that radioactivity is responsible for cell stimulation. In fact the Ins $P_{6}$ synthesis has been studied in model systems outside the animal kingdom: in Dictyostelium (Stephens \& Irvine, 1990), in yeast (Ongusaha et al. 1998; York et al. 1999) and in Spirodela polyrhiza (Brearly \& Hanke, 1996). In all cases Ins $(1,3,4,5,6) P_{5}$ was identified as the immediate precursor of the Ins $P_{6}$. Nevertheless, the controversy about the Ins $P_{6}$ synthesis in animal cells continues and the pathways of $d e$ novo Ins $P_{6}$ formation in such cases are not established (Sasakawa, 1995). On the other hand, Ins $P_{6}$ is widespread in the vegetal kingdom, mainly in seeds, and as a consequence, has been an important dietary component of animals and man from ancient ages.

Ins $P_{6}$ may be involved in the control of several intra- and extracellular physiological processes. Thus, diverse groups have suggested that Ins $P_{6}$ might participate in the intracellular regulations of surface receptions channels (O’Rourke et al. 1996; Efanov et al. 1997; Larsson et al. 1997). Moreover, a number of actions, such as extracellular mediator of Ins $P_{6}$, were pointed out (Vallejo et al. 1987; Luttrel, 1993). In addition, antioxidant properties have been described (Hawkins, 1993) and a potent activity for preventing pathological calcifications was also demonstrated (Grases et al. 1998; Conte et al. 1999; Grases et al. $2000 a, b)$.

All these aspects commented on seem to indicate an important biological role of $\operatorname{Ins} P_{6}$, but a number of unclear facts need further study and clarification (Menniti et al. 1993; Irvine, 1995). Thus, as has been pointed out earlier, the majority of data related to $\operatorname{Ins} P_{6}$ cell content has been evaluated through cell cultures and radioactive measurements after long-term culture with radioactive inositol. Undoubtedly, an important missing clue to the possible importance and functions of Ins $P_{6}$ is the determination of its real levels in different mammalian tissues. In the present

Abbreviation: Ins $P$, inositol phosphate.

* Corresponding author: Dr Felix Grases, fax +34 9711734 26, email dqufgf0@ps.uib.es 
study, Ins $P_{6}$ was determined in rat tissues fed on diets with different Ins $P_{6}$ contents, using a $\mathrm{GC}-$ mass detection methodology that permitted the evaluation of the total amount of this substance present in such tissues.

\section{Material and methods}

\section{Animals and diets}

Female Wistar rats (21-d-old) from Harlan Ibérica S.A. (Barcelona, Spain) were acclimated to our animal house for $7 \mathrm{~d}$ and kept on diet and tap water ad libitum. The rats were housed two animals per cage at a temperature of $23 \pm 1{ }^{\circ} \mathrm{C}$ and relative humidity of $50 \%$ with a $12 \mathrm{~h}$ light-dark cycle. The animals were assigned randomly to three groups of twelve rats each.

The diets used were AIN-76A (Harland Tekland, Madison, WI, USA), a purified diet in which $\operatorname{Ins} P_{6}$ is undetectable, an AIN-76A diet to which phytate dodecasodium salt from corn (Sigma-Aldrich, Madrid, Spain) was added (AIN-76A+10g Ins $P_{6} / \mathrm{kg}$ ) and the standard nonpurified diet pellets (UAR A03; Panlab s.1., Barcelona, Spain). Each experimental group (AIN-76A, AIN-76A+10 g Ins $P_{6} / \mathrm{kg}$ and standard non-purified diet) was fed on one of the different diets for 12 weeks. Representative compositions of AIN-76A, AIN-76A $+10 \mathrm{~g}$ Ins $P_{6} / \mathrm{kg}$ and standard non-purified diets are shown in Table 1.

On the final day of the experiment, urine was collected for $24 \mathrm{~h}$ by housing the rats of the respective groups in different metabolic cages (Tecniplast Gazzada s.a.r.1.; Buguggiate, Italy) and the next day all animals were anaesthetised with pentobarbital $(50 \mathrm{mg} / \mathrm{kg}$, intraperitoneal), killed, and kidneys, liver, brain, bone (femur) and blood were removed.

The procedures used in this experiment were made according to the Directive 86/609/EEC regarding the protection of animals used for experimental and other scientific purposes.

\section{Reagents}

All chemicals were of analytical reagent grade. Granular activated $\mathrm{C}$ (100 mesh) and $\mathrm{Na}_{2}$ EDTA were purchased from
Panreac (Barcelona, Spain), the anion exchange resin was AG 1-X8 (200-400 mesh) from Bio-Rad (Hercules, CA, USA), and Ins $P_{6}$ (from corn), scyllo-inositol, myo-inositol, pyridine (anhydrous), hexane, methanol, chloroform and TCA were from Sigma (Madrid, Spain).

Derivation chemicals, 1,1,1,3,3,3-hexamethyldisilazane and chlorotrimethylsilane, were purchased from Aldrich (Steinheim, Germany). Crude phytase from Aspergillus ficcum, 3.5 units specific activity/mg was from Sigma. A suspension containing $1.0 \mathrm{mg}$ crude phytase $/ \mathrm{ml}$ was prepared in $3 \times 10^{-3} \mathrm{M}-\mathrm{HCl}$ solution with magnetic stirring.

\section{Sample treatment for mineral determination}

Treatment of kidney, liver, brain and plasma. The kidney, liver, brain and plasma were lyophilised (Cryodos; Telstar, Barcelona, Spain) to constant weight and ashed in a muffle furnace at $500^{\circ} \mathrm{C}$ for $24 \mathrm{~h}$ until white ash was attained. The ash was dissolved in $1 \mathrm{M}-\mathrm{HCl}$ and the concentrations of $\mathrm{Ca}$, $\mathrm{Mg}, \mathrm{P}$ and $\mathrm{Zn}$ were determined by inductively-coupled plasma atomic emission spectrometry.

Treatment of bone. The bone samples were pulverised to a uniform blend and were dissolved with $12 \mathrm{M}-\mathrm{HCl}$. A portion of this solution was diluted for convenience to carry out the analysis of mineral content.

Treatment of urine. A portion of urine was diluted to convenience with $1 \mathrm{M}-\mathrm{HCl}$. This solution was used to carry out the analysis of mineral content.

\section{Sample treatment for phytate determination}

Treatment for kidney, liver and brain. Tissues were rapidly frozen at $-20^{\circ} \mathrm{C}$ to reduce any metabolic activity. For analysis it was lyophilised and pulverised to a uniform blend. The lipids were removed according to Folch's method (Folch et al. 1957). An appropriate amount of sample was twice treated with $3 \mathrm{ml}$ chloroform-methanol $(2: 1, \mathrm{v} / \mathrm{v})$. The liquid phase was discarded and the solid phase was homogenised in $5 \mathrm{ml}$ water using an Ultra-Turrax homogeniser (Staufen, Germany) (20 s at $13500 \mathrm{rpm}$, three times). $0 \cdot 1 \mathrm{ml} 0 \cdot 1 \mathrm{M}-\mathrm{Na}_{2}$ EDTA for each $20 \mathrm{mg}$ tissue were added, and the mixture stirred for $1 \mathrm{~h} .0 \cdot 2 \mathrm{ml} 1 \mathrm{M}$-TCA (for

Table 1. Composition of AIN-76A purified diet, AIN-76A diet+10 g phytate/kg and UAR A03 standard non-purified diet*

\begin{tabular}{llcc}
\hline & $\begin{array}{c}\text { AIN-76A } \\
(\mathrm{g} / \mathrm{kg} \mathrm{DM})\end{array}$ & $\begin{array}{c}\text { AIN-76A+phytate } \\
(\mathrm{g} / \mathrm{kg} \mathrm{DM})\end{array}$ & $\begin{array}{c}\text { UAR-A03 } \\
\text { (g/kg DM) }\end{array}$ \\
\hline Protein & 203 & 203 & 267 \\
Carbohydrate & 650 & 632 & 565 \\
Lipid & 50 & 50 & 57 \\
Cellulose & 50 & 50 & 45 \\
Ash & 47 & 65 & 66 \\
Calcium & 3.91 & 4.45 & 9.90 \\
Magnesium & 0.47 & 0.50 & 1.85 \\
Zinc & 0.028 & 0.028 & 0.045 \\
Phosphorus $†$ & $7 \cdot 20$ & 7.84 & 5.30 \\
Phytate & Undetectable & 11.6 & 9.0 \\
Water & 58 & 64 & 111 \\
\hline
\end{tabular}

*AIN-76A: Harland Tekland, Madison, WI, USA; UAR A03: Panlab s.I., Barcelona, Spain.

†Excludes phosphorus from phytate. 
each $20 \mathrm{mg}$ tissue) were added to denaturise protein. The solid phase was separated by centrifugation at $3500 \mathrm{rpm}$ for 5 min. The supernatant was quantitatively transferred to a vial, and neutralised with $\mathrm{NaOH}$ to $\mathrm{pH} \mathrm{3-4.} \mathrm{Using} \mathrm{this}$ solution, the procedure described later for $\operatorname{Ins} P_{6}$ determination was followed.

Treatment of plasma. Whole blood in $6 \mathrm{Iu}$ heparin $/ \mathrm{ml}$ was centrifuged at $3500 \mathrm{rpm}$ for $15 \mathrm{~min}$. Portions of the supernatant fraction were treated with $0 \cdot 1 \mathrm{ml} 0 \cdot 1 \mathrm{M}-\mathrm{Na}_{2}$ EDTA and $0.2 \mathrm{ml} 1 \mathrm{M}-\mathrm{TCA} / \mathrm{ml}$ plasma. Using this solution, the procedure described later for $\operatorname{Ins} P_{6}$ determination was followed.

Treatment of bone. The sample, pulverised to a uniform blend, was shaken with $0.2 \mathrm{ml} 12 \mathrm{M}-\mathrm{HCl}$ for $3 \mathrm{~h}$. The suspension was then diluted to $\mathrm{pH} 3-4$ and filtered through a $0.45 \mu \mathrm{m}$ filter. The method continued as in the procedure described later.

Treatment of urine. Urine was acidified with $\mathrm{HCl}$ to $\mathrm{pH}$ 3-4. The sample was purified using a chromatographic column with $0.5 \mathrm{~g}$ activated $\mathrm{C}$, and analysed as in the procedure described later.

\section{Separation of phytic acid from lower inositol ester, myo-inositol and scyllo-inositol}

The separation of phytic acid from $\operatorname{Ins} P_{5}, \operatorname{Ins} P_{4}, \operatorname{Ins} P_{3}$ free myo-inositol and scyllo-inositol was carried out using a strong anionic exchange resin (AG 1-X8, 200-400 mesh; Bio-Rad). It is known that phytic acid is strongly retained on such resin at $\mathrm{pH}>1.5$ (March et al. 1998). However, inositols are not retained and $5 \mathrm{ml} 3 \times 10^{-3} \mathrm{M}-\mathrm{HCl}$ was sufficient for complete elution of lower inositol ester and inositols. These results were supported by several recovery experiments carried out with four different matrices: standards, artificial urine, human urine and rat kidney (March et al. 2000).

\section{Hydrolysis of phytic acid}

The hydrolysis of phytic acid to inositol can be accomplished by heating it in acid media for a long time (March et al. 1998) or enzymically (March et al. 1995). The results obtained from the study of the enzymic hydrolysis led to the following conclusions: (1) no interaction of free inositol with the enzyme was detected; (2) the yield of the hydrolysis reached a maximum for a $0.5 \mathrm{~h}$ incubation time; (3) phytic acid was quantitatively transformed to myoinositol.

\section{Phytate determination}

Ins $P_{6}$ in organs, plasma and urine was determined essentially according to March et al. (2000). A chromatographic column $(16 \times 5 \mathrm{~mm})$ containing $0.2 \mathrm{~g}$ anionic resin was equilibrated with $3 \times 10^{-3} \mathrm{M}-\mathrm{HCl}$. Solutions of phytic acid at $\mathrm{pH} 3-4$, containing from 0.004 to $0.100 \mu \mathrm{g}$ (as phytic acid) were passed through the column, where phytic acid was retained. The column was washed with $7 \mathrm{ml}$ $3 \times 10^{-3} \mathrm{M}-\mathrm{HCl}$. Then, $0.5 \mathrm{ml} 3 \times 10^{-3} \mathrm{M}-\mathrm{HCl}$ and $0.1 \mathrm{ml}$ phytase enzyme suspension were added, and the column was closed. Its content was mixed by rotation at $1 \mathrm{rpm}$ for
$1 \mathrm{~h}$ at $37^{\circ} \mathrm{C}$. The liquid phase was transferred to a vial and the column washed with $2 \mathrm{ml} 0.05 \mathrm{M}-\mathrm{HCl}$. Scyllo-inositol, $(0 \cdot 01 \mu \mathrm{g}$ in aqueous solution) was added to the vial (internal standard). Then it was frozen at $-20^{\circ} \mathrm{C}$ and lyophilised. The residue was reconstituted by $1 \mathrm{ml}$ pyridine and $0.2 \mathrm{ml}$ hexamethyldisilazane and $0.7 \mathrm{ml}$ chlorotrimethylsilane were added. The solution was maintained at $100^{\circ} \mathrm{C}$ for $1 \mathrm{~h}$. After reaction, the excess of reagents and organic solvent were blown off in a stream of $\mathrm{N}_{2}$. The solid residue was extracted with $2 \mathrm{ml}$ hexane. The solution obtained was evaporated and the residue reconstituted in $200 \mu \mathrm{l}$ hexane. Of this solution, $1 \mu \mathrm{l}$ was injected into a GC-MS (Shimadzu QP-5000 gas chromatograph (Kyoto, Japan) using fused silica capillary column SPB-20 (Supelco, Bellefonte, PA, USA) and He as carrier gas). The calibration graph was obtained from peak height corresponding to the silylated compounds of scyllo- and myo-inositol, at 13.8 and $14 \cdot 5$ min respectively.

The detection limit of the method was $9 \mu \mathrm{g}$ phytic acid/l. The CV of analysed real samples ranged from $2 \cdot 1$ to $2 \cdot 8 \%$. Biological samples contain significant amounts of myoinositol phosphate as well as a number of myo-inositol polyphosphates (Bunce et al. 1993). Then, the interference from lower esters than $\operatorname{Ins} P_{6}$ was studied. Working with standards containing $0 \cdot 125 \mu \mathrm{g} \operatorname{Ins} P_{6}$ it was found that $0 \cdot 5 \mu \mathrm{g} \operatorname{Ins}(1,4,5) P_{3}$ and $\operatorname{Ins}(1,3,4,6) P_{4}$ did not cause any significant error. Nevertheless, in the same conditions, Ins $(1,3,4,5,6) P_{5}$ caused a positive interference $(+15 \%)$. The maximum amount of $\operatorname{Ins}(1,3,4,5,6) P_{5}$ tolerated when determining $0 \cdot 125 \mu \mathrm{g}$ Ins $P_{6}$ was $0 \cdot 125 \mu \mathrm{g}$. Considering that the amount of phytic acid retained in the column containing anionic resin, when analysing biological samples, oscillates between 0.004 and $0.100 \mu \mathrm{g} \operatorname{Ins} P_{6}$, and the lower esters in such samples are present at lower concentrations than $\operatorname{Ins} P_{6}$ (the amount of Ins $P_{5}$ in kidney is half of the amount of Ins $P_{6}$ and in brain and bone is a third of Ins $P_{6}$; F Grases, BM Simonet, RM Prieto and JG March, unpublished results), it was concluded that the present method can be considered specific for $\operatorname{Ins} P_{6}$.

\section{Statistics}

Values in the tables and figures are expressed as mean values with their standard errors. One-way ANOVA was used to calculate significance of differences between groups. The Student $t$ test was used to assess differences of means. The SPSS for the Windows program (SPSS, Chicago, IL, USA) was used for statistical computations. A probability of $P<0.05$ was used for assessing statistical significance.

\section{Results}

The amounts of $\operatorname{Ins} P_{6}$ found in blood, urine, kidneys, liver, brain and bone of rats treated with three different diets were determined and are shown in Fig. 1. The mineral status of these tissues was also established and appears in Table 2. As can be deduced from these results, the highest Ins $P_{6}$ concentrations were found in brain, whereas the amounts detected in kidneys, liver and bone were similar to each other and 10-fold less than those detected in brain. When 

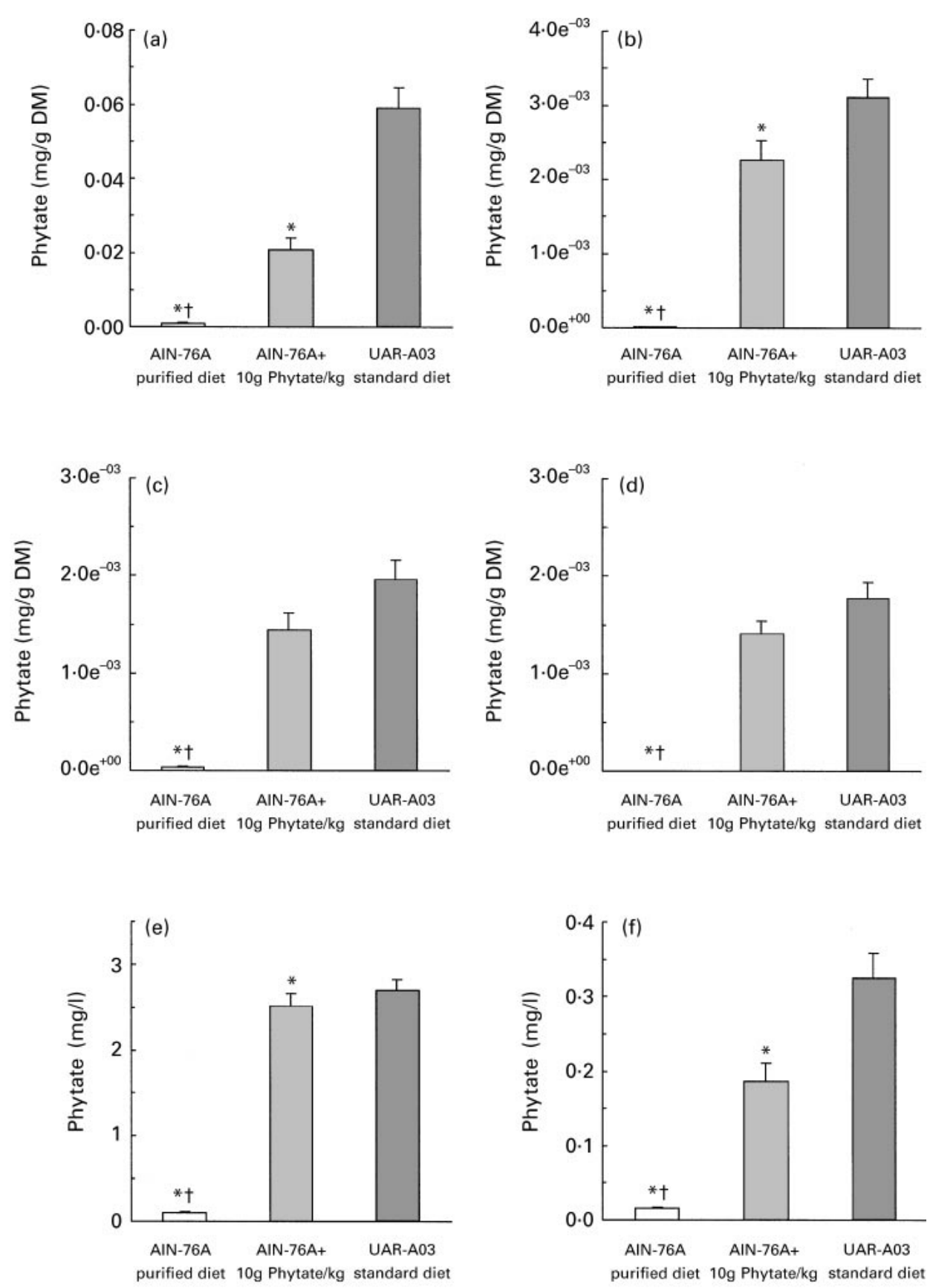

Fig. 1. Phytate concentration in (a) brain, (b) liver, (c) kidney, (d) bone, (e) urine and (f) plasma of rats fed either an AIN-76A diet (Harland Tekland, Madison, WI, USA), AIN-76A diet+10 g phytate/kg or UAR-A03 standard diet (Panlab s.l., Barcelona, Spain) for 12 weeks. Values are mean values for twelve rats per group with standard errors represented by vertical bars. For details of diets and procedures see Table 1 and p. 226. Mean values were significantly different from those of the UAR-A03 standard diet group (student $t$ test): ${ }^{*} P<0.05$. Mean values were significantly different from those of the AIN-76A+10 g phytate/kg diet group: $† P<0.05$.

rats were fed with AIN-76A diet, a purified diet in which $\operatorname{Ins} P_{6}$ is practically absent, the Ins $P_{6}$ levels of the mentioned organs decreased dramatically and in some cases, as in bone, became undetectable. Nevertheless, the addition of Ins $P_{6}$ to the AIN-76A purified diet led to the increase of the Ins $P_{6}$ levels in the tissues mentioned earlier. It is important to observe that no significant differences between the mineral status of the studied tissues, except $\mathrm{Ca}$ in the kidney, as a consequence of the treatment with the three different contents of $\operatorname{Ins} P_{6}$ in the diets, were observed. Rats fed the AIN-76A diet had high Ca concentrations in their kidneys when compared with standard diet-fed rats, whereas the concentration was significantly reduced in rats fed with the AIN-76A+10 g Ins $P_{6} / \mathrm{kg}$.

\section{Discussion}

As can be deduced from the present results Ins $P_{6}$ is widely distributed among animal tissues, the brain being the organ with the highest concentration found and the blood with the 
lowest. It is very important to observe that on removing Ins $P_{6}$ from diet (AIN-76A diet) and after 12 weeks, the Ins $P_{6}$ levels decreased to very low or even undetectable values in all the studied organs and tissues. Nevertheless, the addition of Ins $P_{6}$ to the diet AIN-76A increased the Ins $P_{6}$ levels of the studied tissues, including brain, in spite of the difficulties of crossing the blood-brain barrier. This clearly demonstrated that the majority of the $\operatorname{Ins} P_{6}$ found in organs and tissues has a dietary origin and is not a consequence of endogenous synthesis. Previous studies using rats demonstrated the relationship between the oral administration of Ins $P_{6}$ and its excretion in the urine, so the urinary level declines when Ins $P_{6}$ is withheld and increases with a greater amount of ingested $\operatorname{Ins} P_{6}$, reaching a peak excretion level which is not further increased by ingestion of additional quantities of $\operatorname{Ins} P_{6}$. The minimum amount that gives maximum absorption corresponds to low $\operatorname{Ins} P_{6}$ ingestion (Grases et al. 2000c). Thus, given the mean weight of $279 \mathrm{~g} / \mathrm{rat}$ an ingested amount of $20.9 \mathrm{mg}$ body weight Ins $P_{6} / \mathrm{kg}$ gave the maximum absorption. Considering the Ins $P_{6}$ content of the standard diet (analysed value $9 \mathrm{~g} / \mathrm{kg}$ diet) it is clear that it is enough to provide maximum $\operatorname{Ins} P_{6}$ absorption. Obviously, the diet AIN-76A+10 g Ins $P_{6} /$ $\mathrm{kg}$ diet (analysed value $11.6 \mathrm{~g} / \mathrm{kg}$ ) also has a sufficient Ins $P_{6}$ content to give maximum absorption. Nevertheless, as can be seen in Fig. 1, the Ins $P_{6}$ content of the majority of the tissues was lower in animals fed the AIN-76A+10g Ins $P_{6} / \mathrm{kg}$ when compared with standard diet-fed animals, in spite of excreting similar amounts and presenting similar plasma values. Therefore, such differences in tissue

Table 2. Rat weight, daily ingested food and calcium, magnesium, zinc, and phosphorus concentrations in urine, blood, kidney, liver, bone (femur), and brain of rats fed the AIN-76A diet, the AIN$76 \mathrm{~A}+10 \mathrm{~g}$ phytate/kg diet and standard UAR-A03 diet for 12 weeks $\ddagger \S$

(Mean values with their standard errors for twelve rats per group)

\begin{tabular}{|c|c|c|c|c|c|c|}
\hline \multirow{2}{*}{ Group } & \multicolumn{2}{|c|}{ AIN-76A purified diet } & \multicolumn{2}{|c|}{$\begin{array}{c}\text { AIN- } 76 A+10 \mathrm{~g} \\
\text { phytate } / \mathrm{kg}\end{array}$} & \multicolumn{2}{|c|}{$\begin{array}{l}\text { UAR-A03 } \\
\text { standard diet }\end{array}$} \\
\hline & Mean & SE & Mean & SE & Mean & SE \\
\hline Animal weight (g) & 228 & 7 & 236 & 4 & 240 & 5 \\
\hline Ingested food $(\mathrm{g} / \mathrm{d})$ & $13 \cdot 9^{*} \dagger$ & 0.6 & $15 \cdot 6$ & 0.3 & $16 \cdot 2$ & 0.9 \\
\hline \multicolumn{7}{|l|}{ Urine } \\
\hline Volume (ml) & $16 \cdot 7$ & $2 \cdot 8$ & $18 \cdot 0$ & $1 \cdot 3$ & $16 \cdot 1$ & 1.5 \\
\hline Calcium (mg/l) & $154 \cdot 8^{*}$ & $6 \cdot 8$ & $135 \cdot 2$ & 9.6 & $131 \cdot 2$ & $6 \cdot 8$ \\
\hline Magnesium (mg/l) & 100 & $1 \cdot 2$ & 101 & $1 \cdot 7$ & 107 & $3 \cdot 7$ \\
\hline Zinc $(\mathrm{mg} / \mathrm{l})$ & $0.74^{*}$ & 0.03 & $0.70^{*}$ & 0.02 & 1.97 & 0.05 \\
\hline Phosphorus (mg/l) & 753 & 107 & $815^{\star}$ & 69 & 601 & 32 \\
\hline \multicolumn{7}{|l|}{ Plasma } \\
\hline Calcium (mg/l) & $22 \cdot 1$ & $1 \cdot 1$ & $21 \cdot 4$ & 0.9 & 21.9 & 0.9 \\
\hline Magnesium (mg/l) & $1 \cdot 30$ & 0.05 & $1 \cdot 18$ & 0.05 & 1.36 & 0.08 \\
\hline Zinc $(\mathrm{mg} / \mathrm{l})$ & $6 \cdot 2$ & 0.4 & $6 \cdot 3$ & 0.2 & $6 \cdot 2$ & 0.3 \\
\hline Phosphorus (mg/l) & 128 & 8 & 131 & 8 & 135 & 9 \\
\hline \multicolumn{7}{|l|}{ Kidney } \\
\hline Tissue weight (g DM) & 1.55 & 0.07 & 1.86 & $0 \cdot 18$ & 1.63 & 0.05 \\
\hline Calcium (mg/g) & $17 \cdot 9^{*} \dagger$ & $2 \cdot 1$ & $6 \cdot 28^{*}$ & $1 \cdot 8$ & 0.25 & 0.02 \\
\hline Magnesium (mg/g) & $22 \cdot 8^{*} \dagger$ & $1 \cdot 3$ & $18 \cdot 4^{\star}$ & $0 \cdot 8$ & $10 \cdot 9$ & 0.5 \\
\hline Zinc $(\mu \mathrm{g} / / \mathrm{g})$ & $12 \cdot 2$ & $0 \cdot 7$ & 11.4 & 0.5 & $14 \cdot 0$ & 0.6 \\
\hline Phosphorus (mg/g) & $577^{*} \dagger$ & 29 & $360^{*}$ & 45 & 228 & 11 \\
\hline \multicolumn{7}{|l|}{ Liver } \\
\hline Tissue weight (g DM) & 8.93 & 0.28 & $8 \cdot 21$ & 0.41 & $8 \cdot 29$ & 0.26 \\
\hline Calcium $(\mu \mathrm{g} / \mathrm{g})$ & $18 \cdot 6$ & 0.8 & $18 \cdot 4$ & 0.7 & $18 \cdot 8$ & 0.8 \\
\hline Magnesium $(\mu \mathrm{g} / \mathrm{g})$ & $2 \cdot 35$ & $0 \cdot 13$ & $2 \cdot 20$ & 0.09 & 2.42 & 0.09 \\
\hline Zinc $(\mu \mathrm{g} / \mathrm{g})$ & $11 \cdot 4$ & $0 \cdot 4$ & $11 \cdot 3$ & 0.5 & $14 \cdot 0$ & $0 \cdot 3$ \\
\hline Phosphorus $(\mu \mathrm{g} / \mathrm{g})$ & $6 \cdot 93^{\star} \dagger$ & 0.07 & $6 \cdot 36$ & $0 \cdot 15$ & $6 \cdot 10$ & 0.07 \\
\hline \multicolumn{7}{|l|}{ Bone (femur) } \\
\hline Tissue weight (g DM) & 0.48 & 0.04 & 0.49 & 0.07 & 0.53 & 0.09 \\
\hline Calcium $(\mathrm{mg} / \mathrm{g})$ & 331 & 9 & 323 & 10 & 335 & 10 \\
\hline Magnesium (mg/g) & 3.83 & 0.23 & 3.69 & 0.17 & 3.75 & 0.20 \\
\hline Zinc $(\mathrm{mg} / \mathrm{g})$ & 1.39 & 0.04 & $1 \cdot 28$ & 0.05 & $1 \cdot 39$ & 0.06 \\
\hline Phosphorus (mg/g) & 109 & 5 & 107 & 4 & 113 & 7 \\
\hline \multicolumn{7}{|l|}{ Brain } \\
\hline Tissue weight (g DM) & $1 \cdot 80$ & 0.02 & $1 \cdot 78$ & 0.04 & $1 \cdot 82$ & 0.03 \\
\hline Calcium $(\mu \mathrm{g} / \mathrm{g})$ & 33.3 & $2 \cdot 4$ & $32 \cdot 8$ & $1 \cdot 7$ & $34 \cdot 0$ & $1 \cdot 3$ \\
\hline Magnesium ( $\mu \mathrm{g} / \mathrm{g})$ & 1.83 & 0.02 & $1 \cdot 78$ & 0.03 & 1.85 & 0.03 \\
\hline Zinc $(\mu \mathrm{g} / \mathrm{g})$ & $17 \cdot 2$ & 0.6 & $16 \cdot 5$ & 0.8 & $17 \cdot 1$ & 0.9 \\
\hline Phosphorus $(\mu \mathrm{g} / \mathrm{g})$ & $7 \cdot 80$ & $0 \cdot 12$ & $7 \cdot 70$ & 0.06 & $7 \cdot 81$ & 0.07 \\
\hline
\end{tabular}

Mean values were significantly different from those of the UAR-A03 standard diet group: * $P<0.05$.

Mean values were significantly different from those of the AIN-76A+10 g phytate/kg diet group group: $† P<0.05$ $\ddagger$ AIN-76A: Harland Tekland, Madison, WI, USA; UAR-A03: Panlab s.I., Barcelona, Spain.

$\S$ For details of procedures, see pp. 226-227. 
contents must be a consequence of the different diet composition.

Considering that Ins $P_{6}$ could be implied in some important biological roles, as is pointed out on p. 225 , the value of any diet in supplying this substance is clear. In fact, as it was demonstrated in a previous paper (Grases et al. $2000 \mathrm{~b}$ ), the absence of Ins $P_{6}$ in the AIN-76A diet provoked the development of pathological calcifications in the kidneys of female rats that were prevented with $\operatorname{Ins} P_{6}$ addition to diet. The development of calcifications was also accompanied by anomalous $\mathrm{Ca}$ accumulation in the rat kidneys, whereas this amount was significantly reduced in female rats fed on the AIN-76A $+10 \mathrm{~g} \operatorname{Ins} P_{6} / \mathrm{kg}$. As would be expected, the same results were observed in the present paper (see Table 2). Moreover, low values of urinary Ins $P_{6}$ were also detected in a group of oxalocalcic stone-formers when compared with the urinary levels observed in healthy subjects (Grases et al. 2000a). All these results demonstrate the importance of dietary Ins $P_{6}$ in maintaining adequate levels of this compound in the different organs and tissues.

On the other hand, the tendency at present towards the elimination of Ins $P_{6}$ from the diet in the developed countries as a consequence of the use of refined cereals, low consumption of legumes and nuts etc. can cause an important deficit of Ins $P_{6}$ levels in the organism. This is strengthened by the so-called antinutrient properties of Ins $P_{6}$. In this respect, as can be seen in Table 2 , the amount of Ins $P_{6}$ added to the AIN-76A diet did not significantly affect the animals' mineral status. Nevertheless, it is clear that the administration of large amounts of Ins $P_{6}$, together with diets of a poor mineral content, can produce deficiencies in mineral element status by a decreased mineral bioavailability, according to the data in the literature (Maga, 1982; Anonymous, 1987; Harland \& Oberleas, 1987; Hurrell, 1992; Sandstrom \& Sandberg, 1992; Davidsson, 1997; Sandberg, 1999).

Obviously, the administration of high $\operatorname{Ins} P_{6}$ doses, as in the handling of vitamins, must be adequately controlled and the content of minerals of the corresponding diet must be also considered. In fact, several studies demonstrate that if mineral intakes are adequate and cereal or bran intakes are maintained at moderate levels, there should be no adverse effects on mineral biovailability. Thus, intakes of $2 \mathrm{~g}$ Ins $P_{6}$ and as much as $32 \mathrm{~g}$ dietary fibre/d did not generally affect mineral balances when mineral intake was sufficient (Kelsay et al. 1987).

\section{Acknowledgements}

This work was supported by project PM97-0040 of the Spanish DGESIC. One of the authors, B.M.S., expresses his appreciation to the Spanish Ministry of Education and Culture for a fellowship of the FPI program. We thank C. Cortes-Baileau for technical assistance.

\section{References}

Anonymous (1987) Phytic acid: new doors open for a chelator. Lancet 19, 664-666.

Brearley CA \& Hanke DE (1996) Metabolic evidence for the order of addition of individual phosphates esters in the myo-inositol moiety of inositol hexakisphosphate in the duckweed Spirodela polyrhiza L. Biochemical Journal 314, 227-233.

Bunce CM, French PJ, Allen P, Mountford JC, Moor B, Greaves MF, Michell RH \& Brown G (1993) Comparison of the levels of inositol metabolites in transformed haemopoietic cells and their normal counterparts. Biochemical Journal 289, 667-673.

Conte A, Pizá P, García-Raja A, Grases F, Costa-Bauzá A \& Prieto RM (1999) Test of urinary lithogen risk: usefulness in the evaluation of renal lithiasis treatment using crystallisation inhibitors (citrate and phytate). Archivos Españoles de Urologia 52, 94-99.

Davidsson L, Galan P, Cherouvrier F, Kastenmayer P, Juillerat MA, Hercberg S \& Hurrell RF (1997) Bioavailability in infants of iron from infant cereals: effect of dephytinization. American Journal of Clinical Nutrition 65, 916-920.

Efanov AM, Zaitsev SV \& Berggren P (1997) Inositol hexakisphosphate stimulates non- $\mathrm{Ca}^{2+}$-mediated and primes $\mathrm{Ca}^{2+}-\mathrm{me}-$ diated exocytosis of insulin by activation of protein kinase $\mathrm{C}$. Proceedings of the National Academy of Sciences, USA 94, $4435-4439$.

French PJ, Bunce CM, Stephens LR, Lord JM, McConnell FM, Brown G, Creba JA \& Michell RH (1991) Changes in the levels of inositol lipids and phosphates during the differentiation of HL60 promyelocytic cells towards neutrophils or monocytes. Philosophical Transanctions of the Royal Society of London Series B - Biological Science 245, 193-201.

Folch J, Lees M \& Stanley GHS (1957) A simple method for the isolation and purification of total lipides from animal tissues. Journal of Biological Chemistry 226, 497-509.

Grases F, García-Gonzalez R, Torres JJ \& Llobera A (1998) The effects of phytic acid on renal stone formation in rats. Scandinavian Journal of Urology and Nephrology 32, 262-265.

Grases F, March JG, Prieto RM, Simonet BM, Costa-Bauzá A, García-Raja A \& Conte A (2000a) Urinary phytate in calcium oxalate stone-formers and healthy people. Dietary effects on phytate excretion. Scandinavian Journal of Urology and Nephrology 34, 162-164.

Grases F, Prieto RM, Simonet BM \& March JG (2000b) Phytate prevents tissue calcifications in female rats. Biofactors 11, $171-177$.

Grases F, Simonet BM, March JG \& Prieto RM (2000c) Inositol hexakisphosphate in urine: the relationship between oral intake and urinary excretion. British Journal of Urology International 85, $138-142$.

Harland BF \& Oberleas D (1987) Phytate in foods. World Review of Nutrition and Dietetics 52, 235-259.

Hawkins PT, Poyner DR, Jackson TR, Letcher AJ, Lander DA \& Irvine RF (1993) Inhibition of iron-catalysed hydroxyl radical formation by inositol polyphosphates: a possible physiological function for myo-inositol hexakisphosphate. Biochemical Journal 294, 929-934.

Hurrell RF, Juillerat MA, Reddy MB, Lynch SR, Dassenko SA \& Cook JD (1992) Soy protein, phytate, and iron absorption in humans. American Journal of Clinical Nutrition 56, 573-578.

Irvine RF (1995) Inositide evolution: What can it tell us about functions? Biochemical Society Transactions 23, 27-35.

Jackson TR, Hallam TJ, Downes CP \& Hanley MR (1987) Receptor coupled events in bradykinin action: rapid production of inositol phosphates and regulation of cytosolic free $\mathrm{Ca}^{2+}$ in a neural cell line. EMBO Journal 6, 49-54.

Kelsay JL (1987) Effects of fiber, phytic acid and oxalic acid in the diet on mineral bioavailability. American Journal of Gastroenterology 32, 983-986.

Larsson O, Barker CJ, Sjöholm Å, Carlqvist H, Michell RH, Bertorello A, Nilsson T, Honkanen RE, Mayr GW, Zwiller J \& Berggren P (1997) Inhibition of phosphatases and increased 
$\mathrm{Ca}^{2+}$ channel activity by inositol hexakisphosphate. Science $\mathbf{2 7 8}$, 471-474.

Luttrell BM (1993) The biological relevance of the binding of calcium ions by inositol phosphates. Journal of Biological Chemistry 268, 1521-1524.

Maga JA (1982) Phytate: Its chemistry, occurrence, food interactions, nutritional significance, and methods of analysis. Journal of Agricultural and Food Chemistry 30, 1-9.

March JG, Simonet BM, Grases F \& Salvador A (1998) Indirect determination of phytic acid in urine. Analitica Chimica Acta 367, 63-68.

March JG, Simonet BM \& Grases F (2000) Determination of phytic acid by GC-MS. Application to biological samples. Journal of Chromatography B (In the Press).

March JG, Villacampa AI \& Grases F (1995) Enzymatic photometric determination of phytic acid with phytase from aspergillus Ficuum. Analitica Chimica Acta 300, 269-272.

Menniti FS, Oliver KG, Putney JW \& Shears SB (1993) Inositol phosphates and cell signaling: new views of $\operatorname{InsP}_{5}$ and $\operatorname{InsP}_{6}$. Trends in Biological Science 18, 53-56.

Ongusaha PP, Hughes PJ, Davey J \& Michell RH (1998) Inositol hexakisphosphate in Schizosaccharomyces pombe: synthesis from Ins $(1,4,5) \mathrm{P}_{3}$ and osmotic regulation. Biochemical Journal 335, 671-679.

O’Rourke F, Matthews E \& Feinstein MB (1996) Isolation of InsP 4 and $\mathrm{InsP}_{6}$ binding proteins from human platelets: $\mathrm{InsP}_{4}$ promotes $\mathrm{Ca}^{2+}$ efflux from inside-out plasma membrane vesicles containing $104 \mathrm{kDa}$ GAP1 $1^{\mathrm{IP} 4 \mathrm{BP}}$ protein. Biochemical Journal 315, 1027-1034.
Pittet D, Schlegel W, Lew DP, Monod A \& Mayr GW (1989) Mass changes in inositol tetrakis- and pentakisphosphate isomers induced by chemotactic peptide stimulation in HL-60 cells. Journal of Biological Chemistry 264, 18489-18493.

Sandberg AS, Brune M, Carlsson NG, Hallberg L, Skoglund E \& Rossander-Hulthen L (1999) Inositol phosphate with different numbers of phosphate groups influence iron absorption in humans. American Journal of Clinical Nutrition 70, 240-246.

Sandstrom B \& Sandberg AS (1992) Inhibitory effects of isolated inositol phosphates on zinc absorption in humans. Journal of Trace Elements and Electrolytes in Health and Disease 6. 99-103.

Sasakawa N, Sharif M \& Hanley MR (1995) Metabolism and biological activities of inositol pentakisphosphate and inositol hexakisphosphate. Biochemical Pharmacology 50, 137-146.

Stephens LR \& Irvine RF (1990) Stepwise phosphorylation of myo-inositol leading to myo-inositol hexakisphosphate in Dictyostelium. Nature 346, 580-583.

Szwergold BS, Graham RA \& Brown TR (1987) Observation of inositol pentakis-hexakis-phosphates in mammalian tissues by 31P NMR. Biochemical and Biophysical Research Communications 149, 874-881.

Vallejo M, Jackson T, Lightman S \& Hanley MR (1987) Occurrence and extracellular actions of inositol pentakis- and hexakisphosphate in mammalian brain. Nature 330, 656-658.

York JD, Odom AR, Murphy R, Ives EB \& Wente SR (1999) A phospholiphase C-dependent inositol polyphosphate kinase pathway required for efficient messenger RNA export. Science 285, 96-100. 